\title{
Causal Impact of Government Policy in Stock Market of Nepal
}

\author{
Bhoj Raj Ojha*
}

\begin{abstract}
s
This study is directly related to the semi-strong form of market efficiency. The efficient market hypothesis suggests that stock markets are "informationally efficient". That is, any new information relevant to the market is spontaneously reflected in the stock prices. A consequence of this hypothesis is that past prices cannot have any predictive power for future prices once the current prices have been used as an explanatory variable. In other words the change in future prices depends only on arrival of new information that was unpredictable today hence it is based on surprise information.
\end{abstract}

It examines the relationship between fiscal policy and stock index in Nepal with using data from 2003 to 2019. This research use market model to determine the statistical relationship. Overall the independent variable government policy poses significant relationship with stock index in Nepal.

\section{Background}

The classic definitions of the efficient markets hypothesis (EMH) were made by Fama (1970). Fama states that market in which prices at any time fully reflect available information is called efficient. There are three variants of the hypothesis i) weak ii) semi-strong and iii) strong form. The weak form of the EMH claims that prices on traded assets (e.g., stocks, bonds, or property) already reflect all past publicly available information. The semi-strong form of the EMH claims both that prices reflect all publicly available information and that prices instantly change to reflect new public information. The strong form of the EMH additionally claims that prices instantly reflect even hidden information.

As per Dangol (2008), there are various factors that affect stock market price behavior; they bring out over or under-reaction in the market. A German study by Dopke \& Pierdzioch (2006) is conducted to watch that how much stock market is depending upon Political event.

Unstable political situations reduced foreign investment in stock market and cause volatility because investors are reluctant to invest in more diverse political conditions (Chan \& Wei, 1996).

* Mr. is Ojha Lecturer at Tribhuvan University, Faculty of Management, Shanker Dev Campus Email: birajojha07@gmail.com 
Pantzalis et al (2000) research also indicated a positive stock market reaction in the two weekperiod prior to the election and the positive abnormal return was stronger for elections with higher degree of uncertainty. Preceding results showed that the year of presidential term, presidential elections do systematically influence the rhythm of stock market returns and associated volatilities.

Event study technique is a way to check the impact of different events for short time horizon that how much abnormal returns are generated after happening of an event (Brown \& Warner, 1985).

\section{Statement of Problem}

Clark and Tunaru (2005) defines political events with significant negative economic and financial consequences that are felt everywhere as beside to political events whose economic and financial outcomes are limited to specific country or region. This means that political risk can arise from a large number of sources, which are often mutually dependent.

Koksal and Caliskan (2011), Nishat and Mustafa (2002) found that political developments affect both the returns and the volatility of the stock market, while Malik, Hussain and Ahmed (2009) found that political events affect the stock price due to which the trading volume and stock return fluctuate positively or negatively as per the intensity of the event.

Mei and Guo (2004) examined the impact of political uncertainty on financial crises using a panel of 22 emerging markets. By examining election cycles they found that eight out of nine of the financial crises happened during the periods of election and transition. Using a combination of profit and switching regression analysis, they found that there is a significant relationship between election and financial crisis including an increase in volatility, after controlling for differences in economic and financial conditions. From this they suggest that political uncertainty is a prime contributor to financial crises.

The controversy as to whether fiscal policy exerts any significant influence on stock market activities has been on the front burner of discourse among experts in behavioral finance. While some scholars argue that fiscal policy operations have no effect on stock market activities, others like Plosser (1982), Darrat (1988), McGrattan and Prescott (2001) as well as Afonso and Songa (2009) posit that fiscal actions could affect stock market activities through changes in the rate of interest, portfolio adjustment/revaluation, changes in investment as well as changes in aggregate demand in the economy thus affecting asset prices and the entire economy.

In a cross-country study, Lee (2007) investigated whether fiscal policy affects stock markets in Belgium, France, Germany, United Kingdom and the USA using Granger causality test, Vector Error Correction Model (VECM) and vector autoregressive estimates (VAR) techniques. The study employed quarterly data on stock prices, Federal budget deficits, money supply and 
industrial production from 1974-1998. Empirical results of the study revealed that the stock market in Belgium did not fully capture and reflect publicly available information on fiscal policy proxied by government budget deficits unlike in the other countries where fiscal policy significantly affected aggregate stock prices. The study also found out that the stock markets of all the five countries fully and accurately captured publicly available information on money supply

a) Does government policy affect stock price in Nepal?

\section{Objectives of the Study}

- To examine the role of government policy in stock market.

- To evaluate information efficiency level of Nepalese stock market.

\section{Statement of Hypothesis}

Cutler et al (1989) provided that the political factor do not affect stock price in America. This study had been supported by Lin and Yi (2005), Chen et al. (2005), and Cheian et al. (2013). On the other hand, the research done by Kim and Mei (1994) captured the stock movement in Hong Kong that was tightly related with existing political events. This result was supported by research conducted by Chan and Wei (1996), Kem and Mei (2001), Bilson et al (2002), Ma et al (2003), Zach(2003), Mei and Limim (2004), Beaulieu et al (2005), Goriaev Konstantin (2007), Wang et al (2008), Clack et al (2008), Dangol (2008), Khalid and Gulasekaran(2010), and Wang et al (2013). On the basis of previous research following hypothesis are created.

\section{Alternative Hypotheses:}

$\mathrm{H} 1$ : There is significant relationship between govt. policy and stock index.

In this perspective, the current study will examine the Nepalese stock market reaction to announcements of the political events which will be beneficial for investor as well as finance Government policy covers different policy by the government but in this study government policy relates only to the fiscal policy.

This study only covers the event only from 2003 to 2019.

Mean return model is used to show the relationship between politics and stock market in Nepal and for primary data chi-square test is used for secondary data.

\section{Research Design}

The research design adopted in this study consists of descriptive, correlation and causal comparative research designs to deal with the various aspects. The descriptive research design has developed with the aim of studying the subject of research in detail explains the facts and characteristics related to research problem. It collects and presents the fact and figures in a certain situation. 
The goal of a descriptive study is to describe relevant aspects of the factors of interest to the researcher from an individual, organization or other perspective. An attempt has been made to describe the characteristics of stock price from the political event. The outcomes of price changes from political event are analyzed with different aspects.

\section{Nature and Sources of Data}

This study has utilized both the primary and secondary sources of data. The predictive power of firm specific fundamental and macro-economic variables related to government policy in explaining common stock returns have been tested using secondary sources of data. The overall efficiency of the stock market in Nepal with respect to practitioner's perception has been evaluated using primary data.

\section{Secondary Data}

The study mainly focused secondary data, the data from Nepal stock exchange (NEPSE), and security board of Nepal (SEBON) database, Daily newspaper, BBC websites, NEPSE and SEBON web sites for collecting event data. The study period covered ranges from fiscal year 2003 to 2017.

\section{Primary Data}

The study relies on data from primary sources. The survey questionnaires have been used to collect the practitioners' opinion regarding factors influencing stock prices from political changes in the context of Nepalese stock market. The survey was designed to identify the views of respondents as how they perceive

A total of 700 questionnaires were distributed among investors, securities business persons finance academicians and govt. officers. The questionnaires consisted 9 mixed questions such as ranking, multiple choice and likert scale. Three questions were about respondent profile and demographic information.

Table 1: Response Rate of Questionnaire

\begin{tabular}{|c|l|c|c|c|}
\hline S.No. & Types of respondents & Distributed & Returned & $\begin{array}{c}\text { Response Rate } \\
\mathbf{( \% )}\end{array}$ \\
\hline 1 & Security Business Person & 35 & 24 & 68.57 \\
\hline 2 & Managing Director & 70 & 48 & 68.57 \\
\hline 3 & Investor & 400 & 328 & 82 \\
\hline 4 & Government Officer & 80 & 46 & 57.5 \\
\hline 5 & CA & 35 & 22 & 62.85 \\
\hline 6 & Finance Expert & 80 & 51 & 63.75 \\
\hline & & 700 & 519 & \\
\hline
\end{tabular}

Out of the total 700 questionnaires 35 were distributed to security business persons, 70 were distributed to managing directors of different organizations, 400 were distributed to investors and 80 were distributed to government officers, 35 were distributed to CA, 80 were distributed to finance expert. 


\subsection{Population and Sample}

The population of the study covers all the commercial bank listed in NEPSE by the end of 2017. All price index from different sector are taken for this study. Secondary data are taken from stock indices from 2003 to 2017 listed in NEPSE. Different political event are taken from daily newspaper and internet.

\section{Methods of Data Analysis}

The purpose of the study is to explore the predictive ability of stock prices from political changes. This section deals with statistical and econometric models used in analysis of both primary and secondary data. The method of data analysis are divided into three section. The first section deals with the tools used for analysis of secondary data. This includes correlation analysis, regression analysis. The second section deals with different statistical test of significance for validation of model such as t-test and F-test. The third section provides an overview on methods used for primary data analysis. This includes percentage frequency distribution, cross tabulation, mean ranking scores of responses to Likert scale items and nonparametric test of statistical significance.

\section{Methods of Analysis of Secondary Data}

This study has used econometric models along with other statistical tools to analyze the relationship between stock prices and political event. Simple and multiple regression analysis have been performed by regressing stock prices with explanatory variables. The models used for regressing analysis are described in the following section.

\section{Methods of Analysis of Primary Data}

Primary data analysis has been carried out on the basis of responses derived from questionnaire survey. The questionnaire survey first includes responses to the multiple choices questions. A chi-square test of significance has been carried out to test the significance difference in opinion of the respondents.

Table 2: Selected Event of Fiscal Policy

\begin{tabular}{cllll}
\hline No of & Fiscal Year & Event Date & \multicolumn{1}{c}{ Finance Minister } & \multicolumn{1}{c}{ Party } \\
\hline & & & & \\
\hline $2004 / 2005$ & $2004 / 07 / 16$ & Bharat Mohan Adhikari & UML \\
& $2005 / 2006$ & $2005 / 05 / 12$ & Gynandra Monarchy & Monarchy \\
& $2006 / 2007$ & $2006 / 07 / 01$ & Gynandra Monarchy & Monarchy \\
$2007 / 2008$ & $2007 / 02 / 28$ & Gynandra Monarchy & Monarchy \\
$2008 / 2009$ & $2008 / 09 / 19$ & Baburam Bhattarai & Maoist \\
$2009 / 2010$ & $2009 / 07 / 13$ & Surendra Pandey & UML \\
$2010 / 2011$ & $2010 / 07 / 12$ & Surendra Pandey & UML \\
$2011 / 2012$ & $2011 / 07 / 15$ & Bharat Mohan Adhikari & Maoist \\
$2012 / 2013$ & $2012 / 07 / 15$ & Barsaman Pun & Maoist \\
$2013 / 2014$ & $2013 / 07 / 14$ & Shankar Prasad Koirala & Khil Raj Govt \\
$2014 / 2015$ & $2014 / 07 / 13$ & Ram Sharan Mahat & NC
\end{tabular}




$\begin{array}{llll}2015 / 2016 & 2015 / 07 / 14 & \text { Ram Sharan Mahat } & \text { NC } \\ 2016 / 2017 & 2016 / 05 / 28 & \text { Bishnu Pdr Poudel } & \text { UML } \\ 2016 / 2017 & 2016 / 08 / 04 & \text { Krishna Bdr. Mahara } & \text { Maoist } \\ 2017 / 2018 & 2017 / 06 / 07 & \text { Gynandra Bdr. Karki } & \text { NC } \\ \text { 2018till now } & 2018 / 03 / 16 & \text { Yubaraj Khatiwada } & \text { NCP }\end{array}$

Source: www.bbc.com

\section{Model building}

A technique for determining the statistical relationship between two or more variables where a change in a dependent variable is associated with, and depends on a change in one or more independent variables. (Business Dictionary). Researcher used mean return model for event study as per Brown \& Warner (1985) as they argue it is complete and reliable. Abnormal return is calculated as under: -

ARit $=$ Rit - Rmt i

Where,

$\mathrm{AR}=$ Abnormal Return Rit $=$ Return of the firm Rmt $=$ Market Return

Calculation of Rit as below:

Rit $=\quad \mathrm{P} 1-\mathrm{Pt}-1$

Pt-1 .ii

Where,

P1= Ending price

Pt-1 $=$ Beginning price

$t=\frac{\bar{X}_{1}-\bar{X}_{2}}{S_{p} \sqrt{\frac{1}{n_{1}}+\frac{1}{n_{2}}}}$ iii

Where,

$\bar{x}_{1}=$ Average company return

$\overline{\mathrm{x}}_{2}=$ Average market return

$\mathrm{n}_{1}=$ No. of sample of a company 
$\mathrm{n}_{2}=$ No of sample of market

$S p=$ Sample standard deviation from the

$$
S_{p}=\sqrt{\frac{\left(n_{1}-1\right) s_{1}^{2}+\left(n_{2}-1\right) s_{2}^{2}}{n_{1}+n_{2}-2}}
$$
.iv

Where,

$\mathrm{n}_{1}=$ No. of sample of a company

$\mathrm{n}_{2}=$ No of sample of market

$\mathrm{S}_{1}^{2}=$ variance of company

$\mathrm{S}_{2}^{2}=$ variance of market

\section{Overall Impact of Government Policy on Stock Price}

The Table presents the average daily abnormal returns for day $=-15$ to day +15 . The sample consists of 11 commercial bank from the period of 2003 to 2017. The market model which consists of normal return model. Average abnormal return is the simple average abnormal return for the specified day in even time. The event time is measured in days relative to the government change date.

Table 3: Overall Impact of Government Policy on Stock Price

\begin{tabular}{rrrr}
\hline Day & Abnormal Return & CAR & $t$ test \\
\hline-15 & 2.8656 & 2.8656 & 0.2397 \\
-14 & -0.9849 & 1.8807 & 0.2467 \\
-13 & 3.9425 & 5.8232 & 0.2439 \\
-12 & 10.1137 & 15.9369 & 0.2537 \\
-11 & 5.4424 & 21.3793 & 0.4933 \\
-10 & -5.7226 & 15.6567 & 1.75 \\
-9 & 9.2819 & 24.9386 & 0.4268 \\
-8 & -4.909 & 20.0296 & 0.883 \\
-7 & 2.3928 & 22.4224 & 0.1733 \\
-6 & -2.7924 & 19.63 & 0.1632 \\
-5 & 2.1046 & 21.7346 & 0.1308 \\
-4 & -0.3725 & 21.3621 & 0.1473 \\
-3 & 0.1025 & 21.4646 & 0.1415
\end{tabular}




\begin{tabular}{rrrr}
-2 & 0.3302 & 21.7948 & 0.1399 \\
-1 & 7.7888 & 29.5836 & 0.1408 \\
0 & 5.2354 & 34.819 & 3.2359 \\
1 & 5.8928 & 40.7118 & 3.3256 \\
2 & 4.1304 & 44.8422 & 2.4496 \\
3 & -2.2714 & 42.5708 & 1.8496 \\
4 & -0.2893 & 42.2815 & 1.7632 \\
5 & 1.3448 & 43.6263 & 0.7534 \\
6 & -1.6503 & 41.976 & 0.8047 \\
7 & 1.864 & 43.84 & 0.7298 \\
8 & -2.4784 & 41.3616 & 0.7471 \\
9 & 0.7273 & 42.0889 & 0.6256 \\
10 & -3.1197 & 38.9692 & 0.6246 \\
11 & 3.8817 & 42.8509 & 0.1502 \\
12 & 6.3855 & 49.2364 & 0.3713 \\
13 & 2.054 & 51.2904 & 0.904 \\
14 & -3.0299 & 48.2605 & 0.4203 \\
15 & 0.4667 & 48.7272 & 0.6025 \\
\hline
\end{tabular}

Table 4: Government Policy Influence Stock Market

\begin{tabular}{lccc}
\hline & Observed N & Expected N & Residual \\
\hline Strongly Agree & 295 & 129.8 & 165.3 \\
\hline Agree & 146 & 129.8 & 16.3 \\
\hline Neutral & 58 & 129.8 & -71.8 \\
\hline Disagree & 20 & 129.8 & -109.8 \\
Strongly Disagree & 0 & 0 & 0 \\
\hline Total & 519 & & \\
\hline
\end{tabular}

\section{Major Findings}

- In the case of govt. policy (fiscal policy) on stock price the average abnormal returns are $5.2354 \%$ and $t$ value is 0.23 .

- In the case of Maoist govt. fiscal policy, during the announcement day average abnormal returns is $-2.62 \%$ and $t$ value is 2.82 and after the event date it is 2.83 .

- In the case of NC govt. fiscal policy, during the announcement, average abnormal returns is -0.4695 and $t$ value is 0.99 and after the event date it is 0.6349 and $t$ value is 0.99 .

- In the case of UML govt. fiscal policy, during the announcement day it was 0.4695 and $t$ value is 0.99 and after the event day it was 0.6449 and $t$ value is 0.99 . 


\section{Conclusion}

The current study supports the findings of Afonso and Songa (2009) that fiscal actions could affect stock market activities but this study does not support to the findings of like Plosser (1982), Darrat (1988), McGrattan and Prescott (2001) that fiscal policy operations have no effect on stock market activities.

\section{References}

Afonso, A., \& Sousa, R. M. (2009). The macroeconomic effects of fiscal policy. European Central Bank, Working paper series No 991. Retrieved from http:/ / www.ecb.europa.eu

Beaulieu, M. C., Cosset, J. C., \& Essaddam, N. (2005). The impact of political risk on the volatility of stock returns: The case of Canada. Journal of International business studies, 36(6), 701718.

Bilson, C.M., Brailsford, T.J., \&Hooper, V.C. (2002). The explanatory power of political risk in emerging markets. International Review of Financial Analysis, 11(1), 1-27

Brown, R.I., \& Warner, J.B. (1985). Using daily stock returns: The case of event studies. Journal of Financial Economics, 14(1), 3-31

Brown, S.J., \& Warner, J.B. (1985). Using daily stock returns: The case of event studies. Journal of Financial Economics, 14(1), 3-31. http:/ / dx.doi.org/10.1016/0304-405X(85)90042-X

Chan, Y., \&JohnWei, K. C. (1996). Political risk and stock price volatility: The case of Hong Kong. Pacific-Basin Finance Journal, 4(2/3), 259-275. doi:10.1016/0927-538x(96)00014-5

Chan, Y.C., \& Wei, K.J. (1996). Political risk and stock price volatility: The case of Hong Kong. Pacific-Basin Finance Journal, 4(2/3), 259-275.

Chen, M.H., Kim, W.G., \& Kim, H.J. (2005). The impact of macroeconomic and nonmacroeconomic forces on hotel stock returns. International Journal of Hospitality Management, 24(2), 243-258.

Chen, X., Favilukis, J., \&Ludvigson, S.C. (2013). An estimation of economic models with recursive preferences. Quantitative Economics, 4, 39-83

Clark, E. A., Masood, O., \& Tunaru, R. (2008). The effect of political events on the Pakistan Stock Exchange 1947-2001. Investment Management and Financial Innovations, 5(3), 101110

Clark, E., \& Tunaru, T. (2005). The evolution of international political risk 1956-2001. Retrieved from http://repec.org/mmfc05/paper37.

Cutler, D., Poterba, J., \&Summers, L. (1989). What moves stock prices? Journal of Portfolio Management, 15(3), 4-11.

Dangol, J. (2008). Unanticipated political events and stock returns: An event study. Economic Review, 20, 86-110.

Darrat, A.F. (1988). On fiscal policy and the stock market. Journal of Money, Credit and Banking, 20(3), 353-363

Dopke, J., \& Pierdzioch, C. (2006). Politics and the stock market: Evidence from Germany. European Journal of Political Economy, 22(4), 925-943 
Fama, E.F. (1970). Efficient capital markets: A review of theory and empirical work. The Journal of Finance, 25(2), 383-417.

Goriaev, A., \& Konstantin, S. (2007). Is political risk company specific? The market side of the Yukos affair. Retrieved from http://www.ecore.be/Papers/1208172165.pdf

Khalid, A.M., \& Gulasekaran, R. (2010). The impact of political events on financial market volatility: Evidence using a Markov switching process. Globalisation and Development Centre, Bond University, 43-46.

Kim, H.Y., \& Mei, J. (1994). Political risk and stock returns: The case of Hong Kong. Retrieved from https:/ / ssrn.com/abstract=1299474

Koksal, B., \& Caliskan, A. (2011). Political business cycles, partisan politics and the effects of political events on the stock market: Evidence from a Developing Economy. Retrieved from https:/ / ssrn.com/abstract=1941704 or http:/ / dx.doi.org/10.2139/ssrn.1941704

Lee, U. (2007). Stock returns and fiscal policy: additional international evidence. Indian Journal of Economics and Business, 6(2), 241-256.

Lin, C.T., \& Yi, H.W. (2005). An Analysis of political changes on Nikkei 225 stock returns and volatilities. Annals of Economics and Finance, 6(1), 169-183.

Malik. S., Hussain. S., \& Ahmed. S., (2009). Impact of political event on trading volume and stock returns: The case of KSE. International Review of Business Research Papers, 5(4), 354-364

McGrattan, E.R., \& Prescott, E.C. (2001). Taxes, regulations, and asset prices. National Bureau of Economic Research. Retrieved from https:/ / www.nber.org/papers/w8623.pdf

Mei, J., \& Guo, L. (2004). Political uncertainty, financial crisis and market volatility. European Financial Management, 10(4), 639-657.

Mei, J., \&Guo, L. (2004). Political uncertainty, financial crisis and market volatility. European Financial Management, 10(4), 639-657. doi:10.1111/j.1354-7798.2004.00269.x

Nishat, M., \& Mustafa, K. (2002). Anomalies in Karachi Stock Market: Day of the week effect. The Bangladesh Development Studies, 28(3), 55-64.

Pantzalis, C., Stangeland, D.A., \& Turtle, H.J. (2000). Political elections and the resolution of uncertainty: The international evidence. Journal of Banking \& Finance, 24(10), 15751604.

Plosser, C.I. (1982). Government financing decisions and asset returns. Journal of Monetary Economics, 9(3), 325-352.

Wang, K., Sewon, O., \& Claiborne, M. C. (2008). Determinants and consequences of voluntary disclosure in an emerging market: Evidence from China. Journal of International Accounting, Auditing and Taxation, 17(1), 14-30.

Wang, Y., Wu, C., \& Yang, L. (2013). Oil price shocks and stock market activities: Evidence from oil-importing and oil-exporting countries. Journal of Comparative Economics, 41(4), 1220-1239. 